\title{
Photovoltaic solar energy: the Brazilian reality
}

\section{Sakamoto Renato*}

Safety Engineering, Photovoltaic Generation and Power Distribution Networks, Universidad Camilo Jose Cela, Spain

*Corresponding Author: Sakamoto Renato, Safety Engineering, Photovoltaic Generation and Power Distribution Networks, Universidad Camilo Jose Cela, Spain

Received: May 24, 2019; Published: June 18, 2019

DOI: $10.31080 /$ ASPS.2019.03.0315

\begin{abstract}
The searching for diversification of energy resources in Brazil has become extremely necessary due to two main factors.

The first one is the current hydric situation in which the country is passing through; with the scarcity of rain, the generation situation through hydroelectric power plants is being compromised. Since the significant reduction in rainfall, power generation by hydroelectric plants has not been sufficient to supply the demand. Consequently, the need to use thermoelectric power plants has increased the energy price.

Secondly, Secondly, the exploration of renewable energy resources bring flexibility and sustainability. In this scenario, photovoltaic solar energy presents itself as a technology in constant advance in Brazil and around the world. Through a bibliographical review, this article aims to present the principle of the use of this energy, considering the equipment and materials applied to the system, as well as the efficiency they can achieve. In addition, there is a broader view of the use of sunlight to produce electricity through photovoltaic panels and the applications of this technology in specific situations, such as installation on streetlights. The use of photovoltaic energy is a reality that states increasingly in several countries. In Brazil the manufacturing of photovoltaic systems need to reach an industrial scale to reduce costs, technical conditions and the uncertainty of the extent that this market will reach in the coming years also bring difficulties to final consolidation of solar photovoltaic generation in Brazil. There are several uses for a system that generates electricity
\end{abstract}

Keywords: Electricity; Photovoltaics; Sun Light

\section{Introduction}

From the beginning of time mankind has used the planet's natural resources to meet its energy and functional needs, without major concerns about the effects resulting from the inconsequential use of these resources.

Human civilization and the earth's ecosystem are in conflict, and the climate crisis is the most prominent, destructive and threatening manifestation of this clash. However, the search for improvements, research and investments in technologies that use renewable natural resources, for diversification of the energy matrix, have increased. With this, photovoltaic solar energy became better known and expanded its economic and academic market.

The Brazilian state is in an incipient stage in the international scenario, since its position in relation to the public policies of incentive or regulation that promote the insertion of this source of energy in the concessionary electrification networks is recent, the Normative Resolution 482/2012 by Aneel2, which establishes the rules on microgeneration and distributed mini-generation systems.

\section{Photovoltaic Solar Energy}

Photovoltaic solar energy is defined as the energy generated through conversion solar radiation into electricity. This is done by means of a device known as photovoltaic cell that acts using the principle of photoelectric or photovoltaic effect (Figure 1).

Solar Power can also be thought of as "Solar Electricity" and the key to solar power is the solar cell, or photovoltaic (PV) cell. Solar power is one of the most viable and cleanest forms of renewable energy because we can use the suns energy within the sunlight to produce electricity by means of solar cells. The solar cell operates according to what is called the photovoltaic effect, where photo 
means light and voltaic means electricity. Solar cells are more technically called Photovoltaic Solar Cells, Photovoltaics or simply PV's.

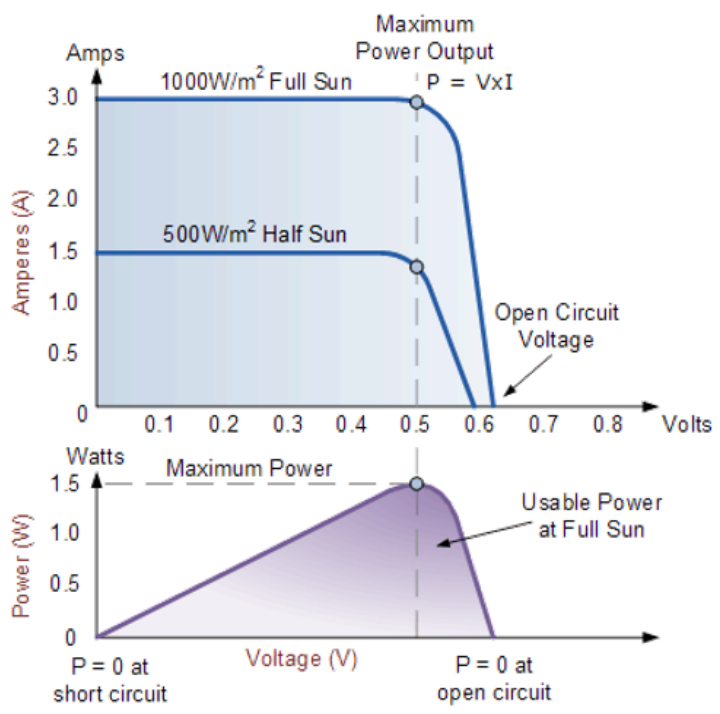

Figure 1: Typical curve of photovoltaic cell behavior. Wenham et al. (2009).

Photovoltaics are silicon semiconductor devices similar in many ways to electronic diodes and transistors. Photovoltaics produce electricity by converting the solar energy generated from the sun in the form of either visible light, ultra-violet (UV) radiation or infra-red (IR) radiation into a direct or DC current by using the photovoltaic action of the cell without the use of any moving parts.

\section{Development of the photovoltaic sector in Brazil}

Brazil started strategic process of inclusion of photovoltaic solar energy large scale in the national electric matrix. In October 2014, the 6th Reserve Energy Auction (LER/2014) resulted in the contracting of 889.7 MW (1,048 MWp or 202.3 MWm) in photovoltaic solar energy projects. At an average price of $\mathrm{R} \$ 215.12$ / MWh, the auction had a discount of $17.89 \%$ in relation to the price established by the government, of R \$262/MWh.

The LER/2014 negotiated 31 photovoltaic projects, with an average installed capacity of $28.7 \mathrm{MW}$ per project. The Normative Resolution ANEEL 481/2012 allows photovoltaic projects of up to 30 MW have an $80 \%$ discount on the Use Rates of the Transmission and Distribution Systems (TUST and TUSD) in the first 10 years of operation, which allows to reduce the final price of energy.
The result of the LER/2014 is the first positive signal from the federal government for the development of a photovoltaic solar energy production chain in the country. However, in order to Brazil be able to develop its photovoltaic industry at the national level, it is still necessary to have specific public policies for the photovoltaic sector. The ideal model of government policies, essential for the development of the sector are: tax and tax exemptions, financial incentives, creation of demand, training and technical training of professionals, expansion of the transmission and distribution infrastructure and extension of the special incentive scheme for infrastructure development.

These actions will create a virtuous cycle of firm demand, development of a national productive chain of inputs, materials, equipment and services, side by side with solid and competitive entrepreneurs.

As in all major industrial markets, you need to have a scale for investment. In the same way, it is fundamental to establish more than one business group of investors to produce each item of interest in the solar photovoltaic system. The presence of more than one local producer of modules, inverters, support structures, glass, cables, etc. competitiveness, competition, quality, reliability and good market practices, avoiding monopolies. This will lead to increasingly competitive pricing, job creation with skilled manpower in the industry and service segments, increased renewable, clean and sustainable energy generation with low greenhouse gas emissions throughout its life cycle and the potential generation of foreign exchange from the export of components, equipment and services.

\section{Distributed generation}

A distributed generation, installed in a pulverized way and generating energy close to consumers, is an important market for the creation of critical mass and scale for the solar photovoltaic sector. In several countries it was fundamental for the development of a national productive chain. It contributes to increasing energy security, promoting greater autonomy in the supply of electricity, by installing several decentralized generating units around the country. This reduces losses in transmission and distribution of electricity and minimizes the costs of electricity supply.

In addition to, avoiding losses and delaying additional investments in transmission lines, it also replaces or complements the power of the network with high tariffs, resulting in savings for the population. 
Normative Resolution No. 482/2012 of ANEEL plays a key role in the insertion of distributed photovoltaic generation in Brazil. It establishes the conditions for the indication of energy credit among energy distribution consumers, that is, it regulates the electric energy compensation system. With this, the generated energy, for instance, through of a photovoltaic solar system installed in a residence or business - may be consumed by other consumer units, contributing to the balance between supply and demand of the electricity system. In practice, the energy generated and injected in the network is interpreted as a product, circulation of goods, therefore, subject to taxation. Regardless of the legal validity of this interpretation, the fact is that the incidence of gross value is substantially the economic benefit of distributed generation, given its importance in the final value of the tariff.

A second fundamental point for the advancement of distributed generation in the country is the establishment of adequate financing lines for the acquisition of photovoltaic systems. And the Northeast region has an average daily incidence between 4.5 and 6 $\mathrm{kWh}$. Alone, these figures put the country at the center of attention in relation to solar potential.

\section{Brazilian potential}

The installed capacity in Brazil, taking into account all types of electricity is 132 gigawatts (GW). Of this total less than $0.0008 \%$ is produced with photovoltaic solar systems. Only this fact makes us reflect on the causes that lead our country to such low use of this abundant source of energy, and with unique characteristics. Brazil is one of the few countries in the world that receives sunstroke (number of hours of sunshine) exceeding 3000 hours per year. What happens is that the electric energy generated that is not consumed instantly is injected into the grid and converted into energy credit with the distributor. This credit may be used by the consumer within 60 months and is taxed.

Effectively, the consumer who has a system of micro and minigeneration pays the ICMS for an energy that he himself generated and "lent" to the network. In 2016, the number of solar micro-generators grew by $407 \%$ over the previous year, according to Aneel data. The sharp expansion occurred mainly in households (80\%). By 2024, the agency stipulates that there will be 886,700 consumer units that will receive credits of this energy, totalling an installed power of approximately $3.2 \mathrm{GW}$.

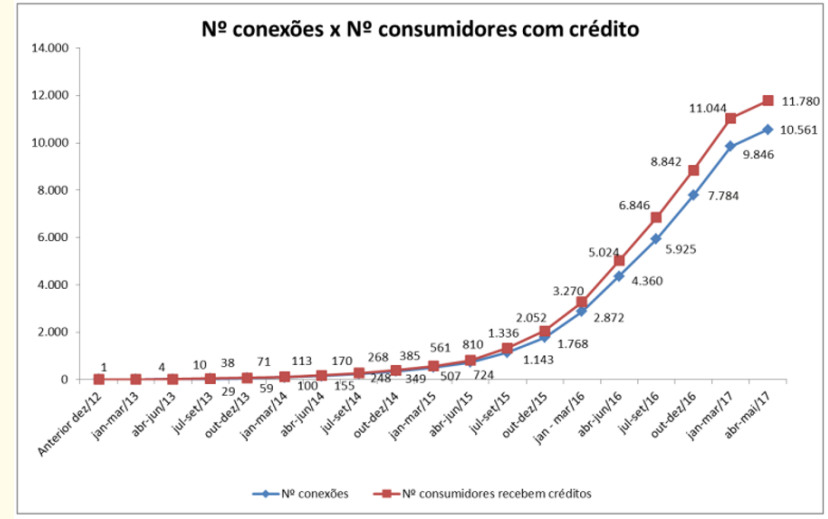

Figure 2: Number of micro and mini-players up to $05 / 23 / 2017$. Technical Note ${ }^{\circ}$ 0056/2017-SRD/Aneel.

\section{Final considerations}

In general, Brazil has been trying, in an incipient way, over the years, to adoptsome measures to stimulate the growth of the use of photovoltaic solar energy; however, what has been done is not sufficient to provide representative growth at the national level in the face of the Brazilian energy matrix.

There are distinct interests in the parties involved in this process, as long as the industry of the photovoltaic energy sector and the professionals seek to leverage their profits the owners of residence seek the possibility of saving in the Energy tariff, but against all interested parties, there is the Public Administration that positions itself so as not to grant exemption from ICMS in some states fearing the effects of the fall of the collection of this tax.

Brazil is experiencing the worst drought crisis of the last 80 years, which had a direct participation in the reduction of generation capacity in the Hydroelectric Power Plants, forcing the operator of the National Electric System to connect the Thermal Power Plants the energy supply [1-15].

\section{Bibliography}

1. Fraidenraich N. "Comparison of the performance of PV water pumping systens driven by fixed, tracking and V-through generators". Solar Energy 76.6 (2004): 703-711.

2. Cresesb. "Energia solar: princípios e aplicações". Rio de Janeiro: CEPEL (2008): 28. 
3. Fraidenraich N and Vilela OC. "Performance of solar systems with non-linear behavior calculated by the utilizability method: application to PV solar pumps". Solar Energy 69.2 (2000): 131-137.

4. Grupo De Trabalho De Energia Solar Fotovoltaica. Manual de engenharia para sistemas fotovoltaicos".Rio de Janeiro: CRESESB (1999): 204.

5. Hinrichs R and Kleinbach M. "Energia e meio ambiente". São Paulo: Pioneira Thompson Learning (2003): 543.

6. Brasil Aneel. "Resolução Normativa no 687, 24 de Novembro de Altera a Resolução Normativa no 482, de 17 de abril de 2012, e os Módulos 1 e 3 dos Procedimentos de Distribuição - PRODIST; (2015).

7. Martins FR., et al. "Scenarios for solar thermal energy applications in Brazil". Energy Policy 48 (2012): 640-649.

8. Bmu Bundesministerium für Umwelt, Naturschutz und Reaktorsicherheit. Disponível em (2006).

9. Jardim CS., et al. "Estudo do Potencial Fotovoltaico em Regiões com Pico de Demanda Diurno na Cidade de Florianópolis". In: ENCAC - COTEDI, Curitiba - PR. (2003).

10. IBGE - Instituto Brasileiro de Geografia e Estatística. Disponível em:

11. IEA - Internactional Energy Agency.

12. Aneel - Agência Nacional de Energia Elétrica.

13. Aitken D and Staden R. "The renewable energy transition". Energy and Transport SDI 14. Disponível em (2005).

14. BEN Balanço Energético Nacional. Sinópse Disponível em (2005).

15. National Solar Jobs Census The Solar Foundation (2013): 60.

\section{Volume 3 Issue 7 July 2019}

(C) All rights are reserved by Sakamoto Renato. 